\title{
Determinants of farmers' tree-planting investment decisions as a degraded landscape management strategy in the central highlands of Ethiopia
}

\author{
Berhan Gessesse ${ }^{1,2,3,4}$, Woldeamlak Bewket ${ }^{3}$, and Achim Bräuning ${ }^{4}$ \\ ${ }^{1}$ Earth Observation Research Division, Entoto Observatory and Research Center, P.O. Box 33679, Addis Ababa, Ethiopia \\ ${ }^{2}$ Department of Geography and Environmental Studies, Kotebe University College, Addis Ababa, Ethiopia \\ ${ }^{3}$ Department of Geography and Environmental Studies, Addis Ababa University, P.O. Box 150372, Addis Ababa, Ethiopia \\ ${ }^{4}$ Institute of Geography, Friedrich-Alexander University of Erlangen-Nürnberg, 91054 Erlangen, Germany
}

Correspondence to: Berhan Gessesse (berhanavu@gmail.com) and Achim Bräuning (achim.braeuning@fau.de)

Received: 23 September 2015 - Published in Solid Earth Discuss.: 13 November 2015

Revised: 9 March 2016 - Accepted: 24 March 2016 - Published: 20 April 2016

\begin{abstract}
Land degradation due to lack of sustainable land management practices is one of the critical challenges in many developing countries including Ethiopia. This study explored the major determinants of farm-level tree-planting decisions as a land management strategy in a typical farming and degraded landscape of the Modjo watershed, Ethiopia. The main data were generated from household surveys and analysed using descriptive statistics and a binary logistic regression model. The model significantly predicted farmers' tree-planting decisions $\left(\chi^{2}=37.29\right.$, $\left.\mathrm{df}=15, P<0.001\right)$. Besides, the computed significant value of the model revealed that all the considered predictor variables jointly influenced the farmers' decisions to plant trees as a land management strategy. The findings of the study demonstrated that the adoption of tree-growing decisions by local land users was a function of a wide range of biophysical, institutional, socioeconomic and household-level factors. In this regard, the likelihood of household size, productive labour force availability, the disparity of schooling age, level of perception of the process of deforestation and the current land tenure system had a critical influence on tree-growing investment decisions in the study watershed. Eventually, the processes of landuse conversion and land degradation were serious, which in turn have had adverse effects on agricultural productivity, local food security and poverty trap nexus. Hence, the study recommended that devising and implementing sustainable land management policy options would enhance ecological
\end{abstract}

restoration and livelihood sustainability in the study watershed.

\section{Introduction}

The sustainability of mankind depends on the wise use of precious environmental capital such as soil, water, vegetation and others in the globalized 21st century world (Keesstra et al., 2016). However, several interwoven earth system components such as the geomorphological, hydrological, climatological, ecological, biogeochemical and anthropogenic processes are very dynamically complex and energetic and are relentlessly changing and shaping the normal provision of the global environment and natural resources (Cerdà, 1998; Keesstra, 2007; Cardinale et al., 2012; Keesstra et al., 2012; Brevik et al., 2015; Decock et al., 2015; Ni et al., 2015; Smith et al., 2015).

As part of the earth's environment and constituents of the watershed landscape ecosystem, land resources such as soil, water and vegetation have a variety of essential life support roles like provisioning, regulating and supporting functions and services (Keesstra et al., 2012, 2016; Berendse et al., 2015; Brevik et al., 2015; Decock et al., 2015; Smith et al., 2015). As a key component of an ecosystem, vegetation is used to regulate biogeochemical cycles (Smith et al., 2015), maintain the energy balance at the earth's surface and mitigate extremes of local climate (Gerten et al., 2004; Gong 
et al., 2015) as well as increase carbon and nitrogen storages and improve land productivity (Yu and Jia, 2014). However, land uses and land covers (LULCs), mainly vegetation covers, have been subjected to change globally in the form of conversion or modification, and their environmental functions and services have destabilized from time to time (Turner and Meyer, 1994; Turner et al., 1994; Geist et al., 2006; Najam et al., 2007; Angassa, 2014; Gong et al., 2015).

Ecological degradation including soil erosion, vegetation and/or biodiversity loss, deterioration of fresh-water resources, extreme-weather events, climate variability and other related environmental problems have resulted from land-use changes (FAO, UNDP, UNEP, 1994; Lambin et al., 2006), and the various constraints on environmental resource development are becoming a serious threat to future development of agrarian nations across the globe. Accordingly, land resources such as soils, water, forests, pastures and wildlife management have been central to the development of human society for a long time (Angassa, 2014; Keesstra et al., 2016).

Similarly to many other environmentally vulnerable nations, Ethiopia has experienced rampant environmental problems over many centuries, which mainly include land degradation in the form of immense wide and deep gully development, soil erosion, vegetation-cover alteration, the disturbance of herbaceous species and water-resource degradation, just to mention a few (Hurni, 1993, Angassa, 2014; Lemenih et al., 2014; Teshome et al., 2014; Gessesse et al., 2015). The massive conversion of vegetation cover and expansion of farming activities, along with the dissected terrain and ecological vulnerable sites and inappropriate farming practices have had serious implications for large-scale geoenvironmental resources. Environmental disgraceful conditions were found both in the lowlands and highlands of Ethiopia (Lakew et al., 2000; Rahmato, 2001; Tefera et al., 2002; Vivero et al., 2005; Assefa and Hans-Rudolf, 2015). These environmental problems lead to the deterioration of soil fertility and productivity. Consequently, the agriculture sector of the country has been hindered by this massive land-resource degradation, which has further contributed to negative impact on the country's economic development at large.

Efforts have been made to monitor environmental changes and to manage as well as restore degraded environments in Ethiopia (Admassie, 2000; Gebremedhin and Swinton, 2003; Frankl et al., 2014). In response to extensive degradation of the resource base and to maximize land productivity, different types of land-resource conservation technologies have been introduced by the successive governments of the country, mainly in the aftermath of the catastrophic drought and famine of the 1970s (Woldemariam, 1992; Hoben, 1995; Admassie, 2000; Rahmato, 2001). Among the introduced land management measures, building physical structures such as stone terraces, soil bunds and agroforestry practices on cultivated fields, as well as area-closure and afforestation measures on degraded hillsides and barren lands were very common in the Ethiopian highlands.
However, land management practices have been seriously constrained by numerous factors. Among others, household-level demographic characteristics, farming practices, profitability of the adopted land-management technologies, agroecological conditions, access to roads and markets, and external factors including land-use policies, property rights, level of extension services and institutional issues are some of the critical factors affecting land-management investment decisions in Ethiopia (Hoben, 1995; Pender and Kerr, 1998; Amsalu and De Graaff, 2007; Bewket, 2007; Ewnetu and Bliss, 2010; Teshome et al., 2014). Lemenih et al. (2014) also argued that the growing importance of cash crop farming systems in different parts of Ethiopia was also aggravating the problem of land-use conversion and landresource degradation, consequently affecting the management of land resources in the country.

Research findings confirmed that vegetation restoration as a land management option is crucial to protect diverse degraded landscapes (Gong et al., 2015), accelerate the recovery of soil-forest functions (Hedo et al., 2015) and overwhelmingly control sediment delivery to the river systems (Keesstra, 2007). Vegetation cover also facilitates soil development over time, stabilizes the direct effect of raindrops on soil, deals with surface runoff, mitigates soil erosion by stabilizing soil aggregation, improves organic carbon sequestration in the soil, and enhances soil porosity and the infiltration rate of soils and is also useful for the conservation and management of soil and water resources (Lieskovský and Kenderessy, 2014; Yu and Jia, 2014; Bruun et al., 2015; Feng et al., 2015; Gong et al., 2015; Qiang et al., 2016).

Although the primary purpose of tree plantation is to secure the demand of fuelwood and charcoal production, it is also used for construction materials, input for farm tools, environmental improvement and many other purposes at the global scale (Rahmato, 2001; Ewnetu and Bliss, 2010; Mukhopadhyay and Maiti, 2014; Haigh et al., 2015). Success to date in terms of widely adopted and sustained realizations of tree-planting investment decisions for the intention of land management strategy has been very limited in the Ethiopian highlands (Admassie, 2000; Rahmato, 2001; Bewket, 2007). Increasingly, focused studies were carried out in Ethiopia to examine the major challenges for the adoption and sustained use of land-management strategies, such as stone terraces and soil bund technologies (Shiferaw and Holden, 1998; Bewket and Sterk, 2002; Bekele and Drake, 2003; Gebremedhin and Swinton, 2003; Hagos and Holden, 2006; Bewket, 2007; Amsalu and De Graaff, 2007) as well as cattle manure (Belay and Bewket, 2013). However, detailed research findings are too scarce to emphasize the determinants of farm-level tree-planting decisions as a land management strategy.

There is, therefore, a need to explore site-specific complexes of biophysical and socioeconomic variables affecting tree-planting investment decisions as a response to restore degraded lands in the highlands of Ethiopia. This study would contribute to bridging this research gap by investigat- 


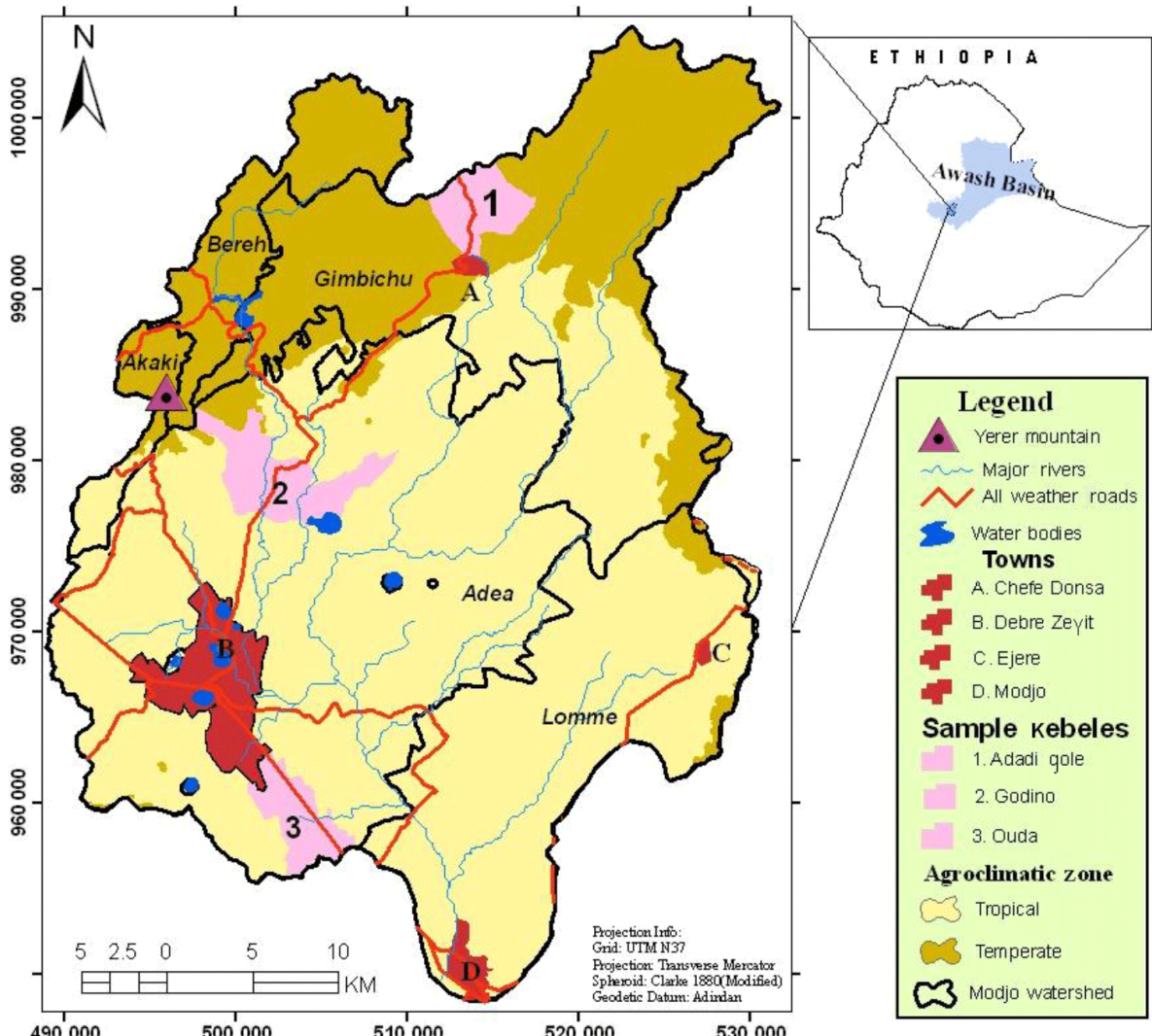

Figure 1. Location map of the Modjo watershed and sample rural kebele administrations.

ing the major determinants of local land users' tree-planting investment decisions in the form of agroforestry, reforestation and afforestation to recover degraded lands. The objectives of this study were (i) to examine the adoption of tree-planting decisions by local land users for reversing landresource degradation and (ii) to investigate major determinants of farm-level tree-growing investment decisions as a land management strategy in a typical rainfed farming landscape of the Modjo watershed.

\section{Materials and methods}

\subsection{Site description}

The study area, the Modjo watershed $\left(\sim 1478 \mathrm{~km}^{2}\right)$, is situated in the East Shewa administrative zone in the Oromia National Regional State of Ethiopia. It is a part of the upper Awash river basin in central Ethiopia, stretching from $8^{\circ} 35^{\prime} 00^{\prime \prime}$ to $9^{\circ} 05^{\prime} 11^{\prime \prime} \mathrm{N}$ and $38^{\circ} 54^{\prime} 35^{\prime \prime}$ to $39^{\circ} 15^{\prime} 30^{\prime \prime} \mathrm{E}$ (Fig. 1). It is also characterized by undulating topography with hills, mountains, plains and river valleys. The physiographic characteristic of the watershed reveals a distinct difference in elevation which ranges from $1740 \mathrm{~m}$ (south of Modjo town) to $3060 \mathrm{~m}$ a.s.l. (at Yerer volcanic ridge). On the basis of Hurni's (1998) and Dejene's (2003) agroecological classification of Ethiopia, the Modjo watershed falls under the weyna dega (tropical) (1740-2300 m) and dega (temperate) $(2300-3060 \mathrm{~m})$ agroecological zones. Based on the FAO (2006) slope classification scheme, the gradient of the Modjo watershed is categorized into flat to very gently sloping ( $9.5 \%$ of the total watershed area), gently sloping to sloping $(61.2 \%)$, strongly sloping to moderately steep (18.4\%) and steep to very steep $(2.9 \%)$. Based on climate data from two selected weather stations at Chefe Donsa town (upstream) and Modjo town (downstream), total annual rainfall is 932 and $824 \mathrm{~mm}$ at the respective stations. The mean annual longterm maximum temperature varies between $23.2^{\circ} \mathrm{C}$ (in the upstream part of the area) and $27.9^{\circ} \mathrm{C}$ (in the downstream part), while the minimum temperature varies from $10.6^{\circ} \mathrm{C}$ (upstream part) to $11.6^{\circ} \mathrm{C}$ (downstream part).

Nine generalized LULC classes including bare land, cultivated land (consisting of croplands with scattered rural settlements), forest, grassland, marshland, plantation areas, shrubs, urban settlements and water bodies were identified in the study watershed based on the 2007 SPOT image classification (Gessesse et al., 2015). Many people depended on both crop cultivation and livestock-rearing livelihoods. Based on population projection, about 625131 people with an average population density of 172 people per $\mathrm{km}^{2}$ lived in and around the Modjo watershed (CSA, 2010). Part of the 
Table 1. Distribution of sample respondents in the Modjo watershed.

\begin{tabular}{lllllrr}
\hline Position & Elevation $(\mathrm{m})$ & Climate zone & District & RKA & Sample size & $\%$ \\
\hline Upstream & $2300-3060$ & Temperate & Gimbichu & Adadi Gole & 32 & 26.45 \\
Midstream & $1740-2300$ & Tropical & Addaa & Godino & 47 & 38.84 \\
Downstream & $1740-2300$ & Tropical & Addaa & Ouda & 42 & 34.71 \\
\hline Grand Total & & & & & 121 & 100 \\
\hline
\end{tabular}

study area is inhabited by urban dwellers, and densely populated areas are observed particularly in and around Chefe Donsa, Godino, Debre-Zeit, Ejeri and Modjo urban landscapes.

\subsection{Data sources and method}

The study was mainly based on a survey of farm households. Feedback from local experts and extension workers regarding critical environmental degradation hotspot sites, the geographical distribution of the sample rural kebele administrations (RKAs), agroecological zones, spatial patterns of the LULCs and land management practices in the upstream, midstream and downstream parts of the watershed were used as criteria for selecting the sample RKAs for the household survey (Fig. 1 and Table 1). We used a multistage sampling design to select the sample households. First, as clearly shown in Fig. 1 and Table 1, the watershed was clustered into upstream, midstream and downstream parts together with the two agroecological zones, namely dega (temperate) and weyna dega (tropical). Second, using the criteria mentioned above, three RKAs, namely Adadi Gole (from the upstream part and dega agroecological zone), Godino (from the midstream part and weyna dega agroecological zone) and Ouda (from the downstream part and weyna dega agroecological zone), were selected. In the third stage, $10 \%$ of sample households were selected from a list of registered households obtained from the respective RKA offices using a lottery randomization approach of simple random sampling technique. One hundred and twenty-one respondents (of which $14.9 \%$ were female household heads) were selected.

Two extension workers in each RKA were trained as data enumerators to carry out the household survey under close supervision of the researchers. A social survey instrument was used to extract information on household characteristics as well as constraints that influence farmers' decisions to plant trees in order to manage their own degraded environment. A structured questionnaire was used to explore the background information of the respondents and factors that are likely to influence the farmers' decisions on tree planting for the purpose of ameliorating land degradation. Finally, the surveyed data were analysed using the Statistical Package for Social Scientists (SPSS), IBM SPSS Statistics for Windows, version 20.0.

\subsection{Model selection and specification}

We analysed data such as household characteristics of the respondents and perceptions of local land users regarding the determinants of farmers' tree-growing decisions using descriptive statistics and a logistic regression model. The outcome variable of local land users' tree-growing decisions was dichotomous, so a binary logistic regression model was used. This statistical model allows for predicting probabilities of tree-growing decisions (the outcome variable) as a function of a set of biophysical and socioeconomic dichotomous or quantitatively measured predictor variables. We also employed the $\chi^{2}$ test of independence to identify possible associations between the outcome and the set of predictor variables. The outcome variable $P_{i}$ is a dummy variable that equals 1 if farmers participated in tree planting as a land management measure and 0 otherwise. Considering the binary logistic regression equation, the probability of the choice to plant trees $\left(P_{i}=1\right)$, or not $\left(P_{i}=0\right)$ is then derived as follows:

$$
P_{i}=\frac{1}{1+e^{-\left(\beta_{0}+\beta_{1} X_{1 i}+\beta_{2} X_{2 i}+\ldots,+\beta_{n} X_{n i}\right)}} .
$$

Conceptually, this model is expected to contain linear relationships (Meyers et al., 2006). However, this assumption is violated due to the dummy nature of the dependent variable considered in the present study. Then, linearizing (transforming odds ratio) the inherent non-linear relationship between explanatory variables $\left(X_{i}\right)$ and the probability of the outcome variable $\left(P_{i}\right)$ using the logarithmic function is one way to fix the limitation of a logistic regression model. Thus, the odds ratio explains the change in the odds of the response variable being other explanatory variables are constant in the model. Accordingly, the probability of choice not to grow trees or the odds ratio is computed as follows:

$\ln [$ odds $]=\frac{P_{i}}{1-P_{i}}$.

To create the relationship between the predictors and odds using the logit (which is the natural logarithm of an odds ratio) function, the $\ln$ of the odds that a case belongs to the response group can be rewritten as follows:

$\ln [$ odds $]=\beta_{0}+\beta_{1} X_{1 i}+\beta_{2} X_{2 i}+\ldots,+\beta_{n} X_{n i}$. 
Table 2. Definition of variables used in the study.

\begin{tabular}{|c|c|}
\hline Variables & Description of variables \\
\hline \multicolumn{2}{|l|}{ Dependent } \\
\hline TREPLANT & If the farmers grew trees to combat land degradation takes, 1 for tree growers and 0 otherwise. \\
\hline \multicolumn{2}{|l|}{ Predictors } \\
\hline GENDER & Sex of the household head, takes 1 for male and 0 otherwise. \\
\hline AGE & Age of household head measured in years. \\
\hline FAMSIZE & Household members in number. \\
\hline LOBFORCE & Number of active household members engaged in farm labour. \\
\hline EDUC & $\begin{array}{l}\text { The literacy status of household heads, takes } 3 \text { from grade } 9 \text { and above, } 2 \text { between grades } 8 \text { and } 1 \text {, } \\
1 \text { for reading and writing only and } 0 \text { otherwise. }\end{array}$ \\
\hline EXPERIAN & Household head's farming experience in the study watershed, takes 1 if greater than 30 years and 0 otherwise. \\
\hline PERCDEFO & $\begin{array}{l}\text { Household head's perception of deforestation process, takes } 1 \text { if they perceive the process of deforestation } \\
\text { and } 0 \text { otherwise. }\end{array}$ \\
\hline LASIZE & Total area of landholding size (cultivated, grazing, homestead and plantation sites) in hectare. \\
\hline LIVESTOC & Total livestock (cattle, equines, sheep and goat) owned by household heads measured in Tropical Livestock Unit (TLU). \\
\hline TRAININ & $\begin{array}{l}\text { Farmers' participation in training and advice schemes organized by natural resource conservation experts and extension } \\
\text { workers } \\
\text { regarding natural resource management at least once in a year, takes } 1 \text { yes and } 0 \text { otherwise. }\end{array}$ \\
\hline LATENURE & $\begin{array}{l}\text { Farmers' perception of land tenure security takes } 1 \text { if the current land tenure system is considered to discourage } \\
\text { planting trees and } 0 \text { otherwise. }\end{array}$ \\
\hline ACESROAD & $\begin{array}{l}\text { Perception of farmers' access to the road to get seedlings and to sell harvested woods, } \\
\text { takes } 1 \text { if they feel road access has positive impacts and } 0 \text { otherwise. }\end{array}$ \\
\hline AGROECOL & $\begin{array}{l}\text { Local agroecology classification, takes the value of } 1 \text { if the site of the sample household head } \\
\text { is weyna dega and } 0 \text { otherwise. }\end{array}$ \\
\hline
\end{tabular}

Then, the ln should be part of the predicted group membership and it can be written as the following:

$g^{\text {pred }}=\ln [$ odds $]=\beta_{0}+\beta_{1} X_{1 i}+\beta_{2} X_{2 i}+\ldots+\beta_{n} X_{n i}$.

Because of the difficulty of interpretation of the logit values, the log odds are transformed into probabilities by taking the antilog of the above equation. The log odds (represented as $g^{\text {pred }}$ ) are now inserted into the antilog function. Therefore, the antilog equation that transforms the log odds to probabilities is derived as follows:

Predicted probability $\left(P_{i}\right)=\frac{e^{g^{\text {pred }}}}{1+e^{g^{\text {pred }}}}$,

where $P_{i}$ is a probability of land users participating in treeplanting decisions (of the outcome being a 1) for the $i$ th sample farmer, $e$ is the base of the natural logarithm and has a value of approximately $2.718 \beta_{0}$ is the intercept (constant); $\beta_{1}, \beta_{2}, \ldots, \beta_{n}$ are the regression coefficients of the corresponding predictor variables $(X \mathrm{~s}) ; X_{1 i}, X_{2 i}, \ldots, X_{n i}$ are predictor (explanatory) variables for the $i$ th farmer; ln stands for the natural log; ln [odds] the natural logarithms of an odds ratio in favour of adopting planting trees as a land management strategy, $1-P_{i}$ is the probability of land users not practicing tree planting to manage their own environment (of the outcome being a 0 ); The $\beta$ coefficient indicates the change in log odds of membership for any 1-unit change in the predictor variables; $g^{\text {pred }}$ is predicted group membership and $e^{g^{\text {pred }}}$ is the antilog value of the natural log-predicted group membership.

\subsection{Variables and hypothesized relationships}

Although a range of explanatory variables were identified and considered in various land-management literature and the use of these variables frequently lacks consistency (Shiferaw and Holden, 1998; Gebremedhin and Swinton, 2003; Bekele and Drake, 2003; Hagos and Holden, 2006; Amsalu and De Graaff, 2007; Mekonnen and Damte, 2011; Mekonnen et al., 2012; Belay and Bewket, 2013; Teshome et al., 2014), the predictor variables of this study were identified based on the consultation with natural-resource conservation experts, background information of the farming systems of the study area and literature of land-resource management. Before running the model, preliminary analyses were carried out to check the presence of multicollinearity among predictor variables and the computed tolerance values of collinearity diagnostics analysis is greater than 0.1 . This shows that there is no perfect multicollinearity between all the considered explanatory variables in the model (Pallant, 2007; Field, 2009).

Furthermore, for this study, the inference of the binary logistic model was undertaken by normalizing one category, which is usually coded as 1 and referred to as "response" or "target" groups, while cases or incidents coded as 0 are sometimes called "referent" or "control" groups (Table 2). Among 
other land-management options, a dichotomous householdlevel tree-planting choice was taken as an outcome variable, whereas a range of household characteristics, institutional and biophysical explanatory variables, which were expected to have an influence on farm-level tree-growing decisions, were considered.

Table 2 presented a description of household-level predictor variables used in the analysis. From the perspective of the existing study site, it is hypothesized that household heads characterized by older age groups, long farming experience and good literacy background would be willing to engage in planting of trees to minimize land degradation problem and enhance productivity of the environment. Male-headed households are more likely to grow trees than their femaleheaded counterparts. Moreover, it is also assumed that households with large family size and large productive labour force are more likely to respond to land-resource degradation through tree planting. Household heads with large landholding size are more likely to grow trees to conserve their own lands and the surrounding environment at large. Access to information through short-term training and advice schemes from extension workers is helpful to increase the probability of farmers' participation in planting trees to manage their own lands. The current state-owned land tenure system might have led to a decrease in the confidence of land users to plant trees. Land users' perception and awareness regarding the deforestation problem is a positive stimulant to plant trees. Similarly, households which owned large livestock herds are less likely to grow trees, but rather they intend to secure more grazing lands. Access to the road is a positive stimulus for households to plant trees, because household heads can easily get seedlings from nearby markets. Finally, households which reside in the downstream part weyna dega agroecological zone) are more likely to have recognized resource degradation and thus to have planted trees than those living in the upstream part (dega agroecological zone).

\section{Results and discussion}

\subsection{Background characteristics of respondents}

The key demographic and socioeconomic characteristics of surveyed households are presented in Table 3. A large percentage of household heads were males $(85.1 \%)$, whereas females constitute the remaining proportion (14.9\%). Large proportions $(85.1 \%)$ of respondents were between the age range of 31 and 64 years, while $9.1 \%$ of them were between 21 and 30, and $5.8 \%$ were between 65 and more years. Household size ranged from 1 to 11 persons per family with an average family size of 5.9 persons. About $37.2 \%$ of respondents had between one and five household members, while a majority $(62.8 \%)$ of them had six or more members in the family. Households with a productive labour force of $1-3,4-6$ and $7-10$ accounted for $45.5,33.9$ and $20.7 \%$ of the sample households respectively. Economically dependent age groups (0-14) and elderly (65 and above) varied from family to family. In this regard, $66.1 \%$ of respondents had household dependency ratios between 0.0 and 0.5 while $33.9 \%$ of households had dependency ratios between 0.5 and 3. On the other hand, $23.1 \%$ of the respondents were illiterate. However, $38.9 \%$ of the respondents could read and write and the educational achievements of $28.1 \%$ of respondents ranged from grade 1 to grade 8 . A small proportion of household heads $(9.9 \%)$ had attended grade 9 and above at school.

Most surveyed households were engaged in a mixed farming system $(70.3 \%)$ and crop cultivation $(27.3 \%)$. Moreover, some of them $(2.5 \%)$ were engaged with off-farm activities like petty trade, daily labour and selling charcoal and wood. Besides, most of the respondents had farming experience of more than 30 years. The landholding of households in the study sites varied from 0.5 to 4.8 ha with an average holding size of 1.8 ha per household. A large majority of the surveyed households ( $62 \%$ from the three sample sites) had often been involved in the planting of trees in the form of afforestation, reforestation, area closure and enrichment tree planting and/or agroforestry systems to reverse land degradation.

\subsection{Determinants of household-level tree planting}

The extent of major determinants of tree-growing decisions as a land management strategy are examined in this study. The analysis shows that most of the sample households $(62 \%)$ participated in tree-planting activities to manage their own lands. However, $38 \%$ of the surveyed farmers did not participate in tree planting (Table 3 ). The effects of the various socioeconomic, demographic, institutional as well as environmental factors on farmers' decisions to plant trees were evaluated using the binomial logistic regression model. The justification for the inclusion of these variables, together with the hypothesized direction of relationship with tree-growing decisions, is explained in the preceding section.

Overall, 121 cases were analysed using the binomial logistic regression model. The model results as presented in Table 4 depicted that the full model significantly predicted farmers' tree-planting decisions $\left(\chi^{2}=37.29, \mathrm{df}=15\right.$, $P<0.001)$. The computed significant value of the model suggested that all the considered predictor variables jointly influenced the farmers' decisions to plant trees to manage their own lands. The model as a whole explained between $27.3 \%$ (Cox and Snell $R^{2}$ ) and $37.1 \%$ (Nagelkerke $R^{2}$ ) of the variance in participation of tree-growing status explained by predictor variables. The current model correctly classified 28 farmers who did not participate in tree-planting activities but misclassified 18 others (it correctly classified $60.9 \%$ of cases). It also correctly classified 62 farmers who were involved in tree-planting practices, but misclassified 13 others (it correctly classified $82.7 \%$ of cases). The overall accuracy of classification was, therefore, the weighted average of these two values $(74.4 \%)$. 
Table 3. Household demographic, socioeconomic and livelihood characteristics.

\begin{tabular}{|c|c|c|c|c|c|c|c|c|}
\hline \multirow[b]{3}{*}{$\begin{array}{l}\text { Demographic and socioeconomic } \\
\text { characteristics }\end{array}$} & \multicolumn{8}{|c|}{ Peasant associations (PAs) } \\
\hline & \multicolumn{2}{|c|}{ Adadi Gole } & \multicolumn{2}{|c|}{ Gudino } & \multicolumn{2}{|c|}{ Ouda } & \multicolumn{2}{|c|}{ Total } \\
\hline & \#32 & $\%$ & \# 47 & $\%$ & \# 42 & $\%$ & \# 121 & $\%$ \\
\hline \multicolumn{9}{|l|}{ Gender } \\
\hline Male & 23 & 22.3 & 43 & 41.8 & 37 & 35.9 & 103 & 85.1 \\
\hline Female & 9 & 50.0 & 4 & 22.2 & 5 & 27.8 & 18 & 14.9 \\
\hline \multicolumn{9}{|l|}{ Age } \\
\hline $21-30$ & 3 & 9.4 & 2 & 4.3 & 6 & 14.3 & 11 & 9.1 \\
\hline $31-40$ & 16 & 50.0 & 12 & 25.5 & 14 & 33.3 & 42 & 34.7 \\
\hline $41-64$ & 13 & 40.6 & 26 & 55.3 & 22 & 52.4 & 61 & 50.4 \\
\hline$\geq 65$ & - & - & 7 & 14.9 & - & - & 7 & 5.8 \\
\hline \multicolumn{9}{|l|}{ Household size $(N)$} \\
\hline $1-5$ & 24 & 75.0 & 4 & 8.5 & 17 & 40.5 & 45 & 37.2 \\
\hline 6 and above & 8 & 25.0 & 43 & 91.5 & 25 & 59.5 & 76 & 62.8 \\
\hline \multicolumn{9}{|l|}{ Productive labour force } \\
\hline $1-3$ & 21 & 65.6 & 12 & 25.5 & 22 & 52.4 & 55 & 45.5 \\
\hline $4-6$ & 11 & 34.4 & 18 & 38.3 & 12 & 28.6 & 41 & 33.9 \\
\hline $7-10$ & - & - & 17 & 36.2 & 8 & 19.1 & 25 & 20.7 \\
\hline \multicolumn{9}{|l|}{ Education } \\
\hline Illiterate & 11 & 34.4 & 17 & 36.2 & - & - & 28 & 33.1 \\
\hline Read and write & 17 & 53.1 & 17 & 36.2 & 13 & 31.0 & 47 & 38.8 \\
\hline Primary school (1-8) & 3 & 9.4 & 10 & 21.3 & 21 & 50.0 & 34 & 28.1 \\
\hline High school and above $(\geq 9)$ & 1 & 3.1 & 3 & 6.4 & 8 & 19.1 & 12 & 9.9 \\
\hline \multicolumn{9}{|l|}{ Farming experience } \\
\hline $21-30 \mathrm{yr}$ & 3 & 9.4 & 2 & 4.3 & 6 & 14.3 & 11 & 9.1 \\
\hline$>30 \mathrm{yr}$ & 29 & 90.6 & 45 & 95.8 & 36 & 85.7 & 110 & 90.9 \\
\hline \multicolumn{9}{|l|}{ Landholding size } \\
\hline $0.50-1.75$ & 11 & 34.4 & 29 & 62.0 & 26 & 61.9 & 66 & 54.5 \\
\hline $1.76-2.75$ & 8 & 25.0 & 14 & 30.0 & 15 & 35.7 & 37 & 30.6 \\
\hline $2.75-4.75$ & 13 & 40.6 & 4 & 9.0 & 1 & 2.4 & 18 & 14.9 \\
\hline \multicolumn{9}{|l|}{ Livelihoods } \\
\hline Only crop cultivation & 0 & 0 & 15 & 31.91 & 18 & 42.9 & 33 & 27.3 \\
\hline Mixed farming & 31 & 96.9 & 30 & 63.8 & 24 & 57.1 & 85 & 70.3 \\
\hline Off-farm activities & 1 & 3.1 & 2 & 4.3 & 0 & 0 & 3 & 2.5 \\
\hline \multicolumn{9}{|c|}{ Involving in tree planting for only the purpose of reversing land degradation } \\
\hline Yes & 16 & 50 & 45 & 95.7 & 14 & 33.3 & 75 & 62 \\
\hline No & 16 & 50 & 2 & 4.3 & 28 & 65.7 & 46 & 38 \\
\hline
\end{tabular}

Table 4 presents the regression coefficients $(\beta)$, the levels of statistical significance and the marginal effects of the odds ratio $[\exp (\beta)]$ together with a $95 \%$ confidence interval $(\mathrm{CI})$ of the odds ratio for each of the predictor variables. The negative or positive signs of the regression coefficients $(\beta)$ of the model present only the direction of the effect of the predictor variables on the dependent variable. The marginal effects of the odds ratio $[\exp (\beta)]$ also represent the probability of a change in the odds of being in one of the outcome categories when the value of a predictor increases by one unit. In gen- 
eral, the estimated coefficients should be compared with the base category of non-participants in tree planting as a land management practice.

The regression results (Table 4) show that local land users' willingness to grow trees was a function of a wide range of factors. The direction of most of the predictor variables used in this model had signs that agreed with our prior expectations. Although land management decisions were constrained by several determinants, their magnitude of influence varies spatially elsewhere to operate successful resource conservation interventions (Shiferaw and Holden, 1998; Herweg and Ludi, 1999; Gebremedhin and Swinton, 2003; Ewnetu and Bliss, 2010; Assefa and Hans-Rudolf, 2014). However, as shown in Table 4, the likelihood of household size (FAMSIZE), productive labour force availability (LABFORCE), disparity of schooling age (EDUC), perception of the deforestation process (PERCDEFO) and the current land tenure system (LATENURE) had positive and significant influences on tree-planting investment decisions.

\subsubsection{Family size (FAMSIZE)}

Results in Table 4 show that household size was one of the demographic variables affecting tree-planting decisions. Large rural family size is on the whole linked with a higher human-labour resource, which would enable a household to realize a range of agricultural activities as well as landresource conservation and management practices.

The result presented in Table 3 confirmed that nearly $37.2 \%$ of the respondents had at least five household members. The remaining had more than five members. This study clearly confirmed that household size was positively and significantly (at $5 \%$ level of significance) correlated with the realization of farm-level tree growing in the forms of afforestation, reforestation and agroforestry systems. The model output revealed that the likelihood of tree planting increases with family size. The marginal effects of the odds ratio show that increasing the size of the household by one unit increases the probability of participation in tree growing by nearly 0.6 times $(95 \% \mathrm{CI}=0.49,2.64)$, other predictor variables being constant in the model. Although the calculated odds ratio is quoted as 0.6 , we can be $95 \%$ confident that the actual value of the odds ratio in the population lay somewhere between 0.49 and 2.64.

This result was in keeping with the findings of previous studies. Studies such as Amsalu and De Graaff (2007) and Alamirew (2011) reported that family size had a positive and significant influence in adopting land management technology, whereas a negative and significant relationship between family size and land-resource management technology adoption was reported by Shiferaw and Holden (1998) and Tadesse and Belay (2004). The same authors commented that households with a larger family size, together with a high dependency ratio, were likely to face food shortages in periods of famine and starvation, so that these households may be forced to sidetrack a fraction of the labour force to off-farm activities to tackle recurring food shortages. As a result, they would be less motivated to invest in land management, where the benefits could only be obtained in the long run.

\subsubsection{Productive labour force availability (LABFORCE)}

The households with a large productive labour force had good opportunities for the adoption as well as application of different types of land-resource management and agricultural technologies. In this study, the effect of productive labour force availability for tree planting to recover degraded landscapes was assessed. The model correlation result was positive and it indicated that households with adequate productive labour were more significantly willing to be involved in tree growing as a degraded-land management strategy. The marginal effects of the odds ratio in the disclosed logistic regression model showed that for every extra number of productive labour force, the odds of the household head's participation in tree growing would be increased by a factor of $0.58(95 \% \mathrm{CI}=0.34,0.89)$, with all other factors remaining equal in the model.

Similar studies carried out in other areas also confirmed that there was a positive and significant relationship between labour availability and land management technology adoption (Pender and Kerr, 1998; Gebremedhin and Swinton, 2003), though these authors used soil conservation technology adoption as a dependent variable. However, Tenge et al. (2004) claimed no significant difference in household labour size between adopters and non-adopters of soil and water conservation measures. This is because implementing soil and water conservation measures depends on (i) decisions about labour allocation, (ii) adopters hiring additional labour to implement soil and water conservation measures from the labour-sharing groups and (iii) adopters also receiving and using remittances from their relatives outside the catchment to hire additional labour.

\subsubsection{Literacy status (EDUCU)}

The study exposed that literate farmers were more involved in tree growing than their counterparts. As can be seen from Table 4, the educational status of the household head significantly increased the probability of planting trees to rehabilitate the degraded environment. The regression coefficient of the three schooling age categories was also positively correlated with tree-planting decisions for the purpose of degraded-land recovery, indicating the existence of a positive relationship between literacy status and land users' treeplanting investment choice. It was indicated that respondents who had schooling levels of only read and write, grade 1 to 8 and grade 9 and above were respectively 15.45, 15.41 and 2.41 times more likely to participate in tree-growing investments than their illiterate counterparts. 
Table 4. Logistic regression results for predicting whether trees are planted by land users using 13 predictors as independent variables.

\begin{tabular}{|c|c|c|c|c|}
\hline & \multirow[b]{2}{*}{$\beta(\mathrm{SE})$} & \multirow[b]{2}{*}{$\operatorname{Exp}(\beta)$} & \multicolumn{2}{|c|}{$95 \% \mathrm{CI}$ for $\operatorname{EXP}(\beta)$} \\
\hline & & & Lower & Upper \\
\hline Intercept & $-1.338(1.842)$ & 0.998 & & \\
\hline GENDER $(1=$ male $)$ & $-0.002(0.725)$ & 0.993 & 0.241 & 4.131 \\
\hline AGE & $-0.007(0.031)$ & 1.612 & 0.935 & 1.755 \\
\hline FAMSIZE & $0.478(0.251)^{* *}$ & 0.579 & 0.486 & 2.636 \\
\hline LOBFORCE & $0.546(0.273)^{* *}$ & 15.452 & 0.339 & 19.990 \\
\hline EDUC $(1=$ only read and write $)$ & $2.738(1.078)^{* * *}$ & 15.415 & 1.867 & 17.869 \\
\hline EDUC $(2=$ from grade 1 to 8$)$ & $2.735(0.953)^{* * *}$ & 2.144 & 2.081 & 9.807 \\
\hline EDUC ( $3=$ grade 9 and above $)$ & $0.763(0.902)^{* * *}$ & 0.430 & 0.366 & 12.553 \\
\hline FAREXPERIAN $(1=>30$ years $)$ & $-0.844(0.697)$ & 1.069 & 0.110 & 1.686 \\
\hline LAHOSIZE & $0.066(0.323)$ & 2.191 & 0.567 & 2.214 \\
\hline PERCDEFO $(1=$ yes $)$ & $0.785(0.487)^{*}$ & 3.066 & 0.858 & 5.600 \\
\hline LATENURE ( $1=$ has an effect $)$ & $1.120(0.498)^{* *}$ & 0.944 & 1.101 & 8.540 \\
\hline TRAININ $(1=$ Yes $)$ & $-0.057(0.514)$ & 0.914 & 0.345 & 2.588 \\
\hline LIVESTOC & $-0.090(0.073)$ & 0.503 & 0.392 & 1.055 \\
\hline AGROECOLO (1 = Weyna dega) & $-0.688(0.776)$ & 0.862 & 0.110 & 2.300 \\
\hline $\operatorname{ACCESROAD}(1=$ yes $)$ & $-0.149(0.777)$ & 0.262 & 0.188 & 3.955 \\
\hline Observation & 121 & & & \\
\hline Model $\chi^{2}$ & $37.29(15)^{* * *}$ & & & \\
\hline-2 Log likelihood & 123.43 & & & \\
\hline Cox and Snell $R^{2}$ & 0.273 & & & \\
\hline
\end{tabular}

NB: $\beta$ is regression coefficients, $\mathrm{SE}$ is standard error, ${ }^{*},{ }^{* *}$ and ${ }^{* * *}$ are levels of significance (probability value) at 10 , 5 and $1 \%$ respectively and $\operatorname{EXP}(\beta)$ is the odds ratio.

The findings of the present study also agreed with previous studies conducted in different regions which had a positive and significant effect of education status as a predictor variable to adopt land management technologies (Pender and Kerr, 1998; Tenge et al., 2004). However, adoption of various forms of soil and water conservation and management technologies were considered as outcome variables. On the other hand, Alamirew (2011) highlighted a contradictory argument by explaining that if land users had a better educational status, she or he may found better opportunities outside the farm sector, reducing labour availability for agricultural and farm management practices.

\subsubsection{Perception of deforestation as an environmental problem (PERCDEFO)}

Local land users' perceptions of deforestation as an environmental predicament together with its negative environmental and socioeconomic impact had influences to plant trees regularly. This study confirmed that land users' perception and awareness regarding the problem of deforestation had a major and affirmative implication on the likelihoods of participating in tree growing. The likelihood of tree growing was 2.19 times $(95 \% \mathrm{CI}=0.86,5.6)$ higher among land users who perceived the magnitude of deforestation compared with those who did not perceive the same way (Table 4). The result correlated well with previous studies conducted elsewhere by Pender and Kerr (1998), Shiferaw and Holden (1998) and
Tenge et al. (2004); however, these authors considered the farmers' perception of environmental degradation as predictor variable and adoption of physical soil conservation measures as a dependent variable.

\subsubsection{Public ownership of land}

Although empirical studies have shown mixed results, it was widely believed that land tenure insecurity leads to inefficient resource use, allocation and management. In this study, an attempt was made to capture the impact of the current land tenure system on the adoption of tree-growing investments in the Modjo watershed. In general, tree growing as a land management measure was a long-term investment with long payback periods so that land users in the study site might seek land tenure security in order to plant trees and keep them in their own farmlands. Findings in Table 4 assert that the current public ownership of land significantly discourages farmers' participation in tree-growing activities in the study area. Studies from elsewhere have also shown that land tenure insecurity was a barrier for the adoption of land management technologies and that tenure security encouraged soil-conservation investments (Shiferaw and Holden, 1998; Gebremedhin and Swinton, 2003; Tenge et al., 2004; Bewket, 2007; Alamirew, 2011). Mekonnen and Damte (2011) and Mekonnen et al. (2012) also found that land certification, as a partial indicator of land tenure security, had increased the likelihood of households growing trees in Ethiopia, however, 
it was not a significant determinant of the number of trees grown.

A number of variables considered in the model including age, sex, land holding size, farming experience, participation in training, livestock ownership status, access to the road and agroecology were found to have non-significant relationship with adoption of tree-growing land management strategy. For example, a positive relationship between landholding size on one hand and the dependent variable of tree-growing decisions on the other hand was expected for the study site, though it was not statistically significant. Contrary to this, the relationship between predictor variables (such as the age and gender of the household heads, farming experiences, participation in short-term training, livestock-ownership status, access to roads and agroecology) with the dependent variable (tree-growing decision) was negative and not significant. Most importantly, variables such as age, gender and participation in short-term training had an unexpected sign in the model and they were non-significant. Thus, further investigation should be needed to examine these cases and to come across conclusive arguments.

\section{Concluding remarks}

This paper examined major determinants of smallholder farmers' tree-planting decisions as a land-management strategy in the Modjo watershed, Ethiopia. The results of the study revealed that the challenges for sustaining the current land-resource management options mainly tree-planting investment decisions were enormous in the study watershed. In this connection, local land users' tree-planting investment achievement was highly compromised by various determinants. Among others, the likelihood of household size, productive labour force availability, the disparity of schooling age, perception of the process of deforestation and the current land tenure system have significantly affected the practice of tree-growing investments. As a result, meaningful results were not achieved in line with tree-planting land-management practices to combat land degradation or degraded-land rehabilitation. Thus, the findings of this study would contribute a lot by providing inputs for stockholders and decision makers to (i) ameliorate determinants of treeplanting investment decisions as well as prioritize, rehabilitate and protect degraded sites; (ii) liberalize land-use policy in order to secure stable land-use rights and legal enforcement of land ownership, which would be essential for materializing tree-planting investment decisions in the study watershed and (iii) raise awareness about the negative impacts of land-resource degradation processes in the Modjo watershed.
Acknowledgements. We would like to extend our special thanks and appreciation to the local farmers, extension workers, as well as the Woreda and zone-level natural-resource conservation experts for their willingness and cooperation during field work and primary data collection phase. We are also very much grateful to the editor and the three anonymous referees for their constructive comments and suggestions. The comments are very helpful for enhancing the quality of the manuscript. Last but not least, we would like to extend our particular gratitude to the Friedrich-Alexander University of Erlangen-Nürnberg for covering the publication cost of this manuscript.

Edited by: A. Jordán

\section{References}

Admassie, Y.: Twenty Years to Nowhere: Property Rights, Land Management and Conservation in Ethiopia, Red Sea Press, Lawrenceville, NJ, USA, 2000.

Alamirew, B.: The impact of poverty, tenure security and risk on sustainable land management strategies in north central Ethiopia: analysis across three agro-ecological zones, J. Sustain. Dev. Africa, 13, 227-240, 2011.

Amsalu, A. and De Graaff, J.: Determinants of adoption and continued use of stone terraces for soil and water conservation in the Ethiopian highlands, Ecol. Econ., 61, 294-302, doi:10.1016/j.ecolecon.2006.01.014, 2007.

Angassa, A.: Effects of grazing intensity and bush encroachment on herbaceous species and rangeland condition in southern Ethiopia, Land Degrad. Dev., 25, 438-451, doi:10.1002/ldr.2160, 2014.

Assefa, E. and Hans-Rudolf B.: Farmers' perception of land degradation and traditional knowledge in southern Ethiopia-resilience and stability, Land Degrad. Develop., doi:10.1002/ldr.2364, online first, 2015.

Bekele, W. and Drake, L.: Soil and water conservation decision behavior of subsistence farmers in the eastern highlands of Ethiopia: a case study of the Hunde-Lafto area, Ecol. Econ., 46, 437-451, doi:10.1016/S0921-8009(03)00166-6, 2003.

Belay, M. and Bewket, W.: Farmers' livelihood assets and adoption of sustainable land management practices in north-western highlands of Ethiopia, Int. J. Environ. Stud., 70, 284-301, doi:10.1080/00207233.2013.774773, 2013.

Berendse, F., van Ruijven, J., Jongejans, E., and Keesstra, S.: Loss of plant species diversity reduces soil erosion resistance, Ecosystems, 18, 881-888, doi:10.1007/s10021-015-9869-6, 2015.

Bewket, W.: Soil and water conservation intervention with conventional technologies in northwestern highlands of Ethiopia: acceptance and adoption by farmers, Land Use Policy, 24, 404-416, doi:10.1016/j.landusepol.2006.05.004, 2007.

Bewket, W. and Sterk, G.: Farmers' participation in soil and water conservation activities in the Chemoga watershed, Blue Nile Basin, Ethiopia, Land Degrad. Dev., 13, 189-200, doi:10.1002/ldr.492, 2002.

Brevik, E. C., Cerdà, A., Mataix-Solera, J., Pereg, L., Quinton, J. N., Six, J., and Van Oost, K.: The interdisciplinary nature of SOIL, SOIL, 1, 117-129, doi:10.5194/soil-1-117-2015, 2015.

Bruun, T. B., Elberling, B., de Neergaard A., and Magid, J.: Organic carbon dynamics in different soil types after conversion 
of forest to agriculture, Land Degrad. Develop., 26, 272-283, doi:10.1002/ldr.2205, 2015.

Cardinale, B. J., Duff, J. E., Gonzalez, A., Hooper, D. U., Perrings, C., Venail, P., Narwani, A., Mace, G. M., Tilman, D., Wardle, D. A., Kinzig, A. P., Daily, G. C., Loreau, M., Grace, J. B., Larigauderie, A., Srivastava, D. S., and Naeem, S.: Biodiversity loss and its impact on humanity, Nature, 486, 59-67, 2012.

Central Statistical Authority (CSA): Statistical Abstract, Ethiopian Central Statistical Agency, Addis Ababa, Ethiopia, 2010.

Cerdà, A.: The influence of aspect and vegetation on seasonal changes in erosion under rainfall simulation on a clay soil in Spain, Can. J. Soil Sci., 78, 321-330, 1998.

Decock, C., Lee, J., Necpalova, M., Pereira, E. I. P., Tendall, D. M., and Six, J.: Mitigating $\mathrm{N}_{2} \mathrm{O}$ emissions from soil: from patching leaks to transformative action, SOIL, 1, 687-694, doi:10.5194/soil-1-687-2015, 2015.

Dejene, A.: Integrated Natural Resources Management to Enhance Food Security, Food and Agricultural Organization of the United Nations, Rome, Italy, 2003.

Ewnetu, Z. and Bliss, J. C.: Tree growing by small holder farmers in the Ethiopian highlands, in: Small Scale Forestry in a Changing World: Opportunities and Challenges and the Role of Extension and Technology Transfer, Ljubljana, Forestry Institute and Slovenia Forest Service, Bled, Slovenia, 6-12 June 2010, 166187,2010

FAO: Guidelines for Soil Profile Description, 4th Edn., Food and Agriculture Organization of the United Nations, Rome, Italy, 2006.

FAO, UNDP and UNEP: Land degradation in south Asia: Its severity, causes and effects upon the people, Food and Agriculture Organization of the United Nations, United Nation Development Programme, United Nation Environmental Programme, Rome, Italy, 1994.

Feng, J., Zhang, C., Zhao, T., and Zhang, Q.: Rapid revegetation by sowing seed mixtures of shrub and herbaceous species, Solid Earth, 6, 573-581, doi:10.5194/se-6-573-2015, 2015.

Field, A.: Discovering Statistics Using SPSS, 3rd edn., SAGE Publications Ltd, Los Angeles, United States, 2009.

Frankl, A., Deckers, J., Moulaert, L., Damme, A. V., Haile, Mitiku, Poesen, J., and Nyssen, J.: Integrated solutions for combating gully erosion in areas prone to soil piping: innovations from the dry lands of northern Ethiopia, Land Degrad. Dev., doi:10.1002/ldr.2301, online first, 2014

Gebremedhin, B. and Swinton, S. M.: Investment in soil conservation in northern Ethiopia: the role of land tenure security and public programs, Agr. Econ., 29, 69-84, doi:10.1016/S01695150(03)00022-7, 2003.

Geist, H., McConnell, W., Lambin, E. F., Moran, E, Alves, D., and Rudel, T.: Causes and trajectories of land-use/cover change, in: Land-Use and Land-Cover Change: Local Processes and Global Impact, Springer, Berlin, Germany, 41-70, 2006.

Gertena, D., Schaphoffa, S., Haberlandtb, U., Luchta, W., and Sitcha, S.: Terrestrial vegetation and water balance-hydrological evaluation of a dynamic global vegetation model, J. Hydrol., 286 249-270, doi:10.1016/j.jhydrol.2003.09.029, 2004.

Gessesse, B., Bewket, W., and Bräuning, A.: Model-based characterization and monitoring of runoff and soil erosion in response to land use/land cover changes in the Modjo watershed, Ethiopia, Land Degrad. Dev., 26, 711-724, doi:10.1002/ldr.2276, 2015.
Gong, Z., Kawamura, K., Ishikawa, N., Goto, M., Wulan, T., Alateng, D., Yin, T., and Ito, Y.: MODIS normalized difference vegetation index (NDVI) and vegetation phenology dynamics in the Inner Mongolia grassland, Solid Earth, 6, 1185-1194, doi:10.5194/se-6-1185-2015, 2015.

Hagos, F. and Holden, S.: Tenure security, resource poverty, public programs, and household plot-level conservation investments in the highlands of northern Ethiopia, Agr. Econ., 34, 183-196, doi:10.1111/j.1574-0864.2006.00117.x, 2006.

Haigh, M., Reed, H., Flege, A., D’Aucourt, M., Plamping, K., Cullis, M., Woodruffe, P., Sawyer, S., Panhuis, W., Wilding, G., Farrugia, F., and Powell, S.: Effect of planting method on the growth of alnus glutinosa and quercus petraea in compacted opencast coal-mine spoils, South Wales, Land Degrad. Develop., 26, 227-236, doi:10.1002/ldr.2201, 2015.

Hedo, J., Lucas-Borja, M. E., Wic, C., Andrés-Abellán, M., and de Las Heras, J.: Soil microbiological properties and enzymatic activities of long-term post-fire recovery in dry and semiarid Aleppo pine (Pinus halepensis M.) forest stands, Solid Earth, 6, 243-252, doi:10.5194/se-6-243-2015, 2015.

Herweg, K. and Ludi, E.: The performance of selected soil and water conservation measures-case studies from Ethiopia and Eritrea, Catena, 36, 99-114, 1999.

Hoben, A.: Paradigms and politics: the cultural construction of environmental policy in Ethiopia, World Dev., 23, 1007-1021, doi:10.1016/0305-750X(95)00019-9, 1995.

Hurni, H.: Land degradation, famines and resource scenarios in Ethiopia, in: World Soil Erosion and Conservation, edited by: Pimentel, D., Cambridge University Press, Cambridge, UK, 27-62, 1993.

Hurni, H.: Agroecological Belts of Ethiopia, Centre for Development and Environment, Wittwer Druck AG, Bern, Switzerland, 1998.

Keesstra, S. D.: Impact of natural reforestation on floodplain sedimentation in the Dragonja basin, SW Slovenia, Earth Surf. Proc. Land., 32, 49-65, doi:10.1002/esp.1360, 2007.

Keesstra, S. D., Geissen, V., van Schaik, L., Mosse, K., and Piiranen, S.: Soil as a filter for groundwater quality, Curr. Opin. Environ. Sustain., 4, 507-516, doi:10.1016/j.cosust.2012.10.007, 2012.

Keesstra, S. D., Bouma, J., Wallinga, J., Tittonell, P., Smith, P., Cerdà, A., Montanarella, L., Quinton, J., Pachepsky, Y., van der Putten, W. H., Bardgett, R. D., Moolenaar, S., Mol, G., and Fresco, L. O.: FORUM paper: The significance of soils and soil science towards realization of the UN sustainable development goals (SDGs), SOIL Discuss., doi:10.5194/soil-2015-88, in review, 2016.

Lakew, D., Kassie, M., Benin, S., and Pender, J.: Land Degradation in the Highlands of Amhara Region and Strategies for Sustainable Land Management, Livestock Policy Analysis Program, Working Paper No. 32, International Livestock Research Institute (ILRI), Nairobi, Kenya, 2000.

Lambin, E.F, Geist, H., and Rindfuss, R. R.: Introduction: local processes with global impacts, in: Land-Use and Land-Cover Change: Local Processes and Global Impacts, Springer, New York, United States and Berlin, 1-8, 2006.

Lemenih, M., Kassa, H., Kassie, G. T., Abebaw, D., and Teka, W. Resettlement and woodland management problems and options: 
a case study from north-western Ethiopia, Land Degrad. Dev., 25, 305-318, doi:10.1002/ldr.2136, 2014.

Lieskovský, J. and Kenderessy, P.: Modelling the effect of vegetation cover and different tillage practices on soil erosion in vineyards: a case study in vráble (Slovakia) using WATEM/SEDEM, Land Degrad. Develop., 25, 288-296, doi:10.1002/ldr.2162, 2014.

Mekonnen, A. and Damte, A.: Private Trees as Household Assets and Determinants of Tree-Growing Behavior in Rural Ethiopia, Discussion Paper 11-14, Resources for the Future and Environment for Development, Washington, DC and Gothenburg, USA, 2011.

Mekonnen, A., Ghebru, H., Holden, S., and Kassie, M.: Impact of Land Certification on Tree Growing on Private Plots of Rural Households: Evidence from Ethiopia, Working Paper 03/12, Center for Land Tenure Studies, Norwegian University of Life Sciences, Oslo, Norway, 2012.

Meyers, L. S., Gamst, G., and Guarino, A. J.: Applied Multivariate Research: Design and Interpretation, Sage Publications, Inc., Thousand Oaks, United States, 2006.

Mukhopadhyay, S. and Maiti, S. K.: Soil $\mathrm{Co}_{2}$ flux in grassland, afforested land and reclaimed coalmine overburden dumps: A case study, Land Degrad. Develop., 2, 216-227, doi:10.1002/ldr.1161, 2014.

Najam, A., Runnalls, D., and Halle, M.: Environment and Globalization: Five Propositions. Unigraphics Ltd, Winnipeg and Manitoba, Canada, 2007.

Ni, J., Luo, D. H., Xia, J., Zhang, Z. H., and Hu, G.: Vegetation in karst terrain of southwestern China allocates more biomass to roots, Solid Earth, 6, 799-810, doi:10.5194/se-6-799-2015, 2015.

Pallant, J.: A Step by Step Guide to Data Analysis Using SPSS for Windows, 3rd Edn., Open University Press, Berkshire, UK, 2007.

Pender, J. and Kerr, J.: Determinants of farmers' indigenous soil and water conservation investments in semi-arid India, Agr. Econ., 19, 113-125, doi:10.1016/S0169-5150(98)00026-7, 1998.

Qiang, F., Wenwu, Z., Jun, W., Xiao, Z., Mingyue, Z., Lina, Z., Yuanxin, L., and Xuening, F.: Effects of different land-use types on soil erosion under natural rainfall in the Loess Plateau, China, Pedosphere, 26, 243-256, Doi:10.1016/S1002-0160(15)60039X, 2016.

Rahmato, D.: Environmental Change and State Policy in Ethiopia: Lessons from Past Experience, Forum for Social Studies Monograph Series 2, Forum for Social Studies, Addis Ababa, Ethiopia, 2001.

Shiferaw, B. and Holden, S.: Resource degradation and adoption of land conservation technologies in the Ethiopian highlands: a case study in Andit Tid, North Shewa, Agr. Econ., 18, 233247, doi:10.1016/S0169-5150(98)00036-X, 1998.
Smith, P., Cotrufo, M. F., Rumpel, C., Paustian, K., Kuikman, P. J., Elliott, J. A., McDowell, R., Griffiths, R. I., Asakawa, S., Bustamante, M., House, J. I., Sobocká, J., Harper, R., Pan, G., West, P. C., Gerber, J. S., Clark, J. M., Adhya, T., Scholes, R. J., and Scholes, M. C.: Biogeochemical cycles and biodiversity as key drivers of ecosystem services provided by soils, SOIL, 1, 665685, doi:10.5194/soil-1-665-2015, 2015.

Tadesse, M. and Belay, K.: Factors influencing adoption of soil conservation measures in southern Ethiopia: the case of Gununo Area, J. Agr Rural Dev. Trop., 105, 49-62, 2004.

Tefera, B., Ayele, G., Atnafe, Y., Jabbar, M. A., and Dubale, P.: Nature and Causes of Land Degradation in The Oromiya Region: a Review, Socioeconomics and Policy Research Working Paper 36, International Livestock Research Institute (ILRI), Nairobi, Kenya, 2002.

Tenge, A. J., De Graaff, J., and Hella, J. P.: Social and economic factors affecting the adoption of soil and water conservation in West Usambara Highlands, Tanzania, Land Degrad. Dev., 15, 99-114, doi:10.1002/ldr.606, 2004.

Teshome, A., De Graaff, J., Ritsema, C., and Menale, K.: Farmers' perceptions about the influence of land quality, land fragmentation and tenure systems on sustainable land management in the north western Ethiopian highlands, Land Degrad. Dev., doi:10.1002/ldr.2298, online first, 2014.

Turner II, B. L. and Meyer, W. B.: Global land-use and land-cover change: an overview, in: Changes in Land Use and Land Cover: a Global Perspective, Press Syndicate of the University of Cambridge, Cambridge, New York, United States and Melbourne, 310, 1994.

Turner II, B. L., Meyer, W. B., and Skole, D. L.: Global landuse/land-cover change: towards an integrated study, Ambio, 23, 91-95, 1994

Vivero, J. L., Kelbessa, E., and Demissew, S.: The Red List of Endemic Trees and Shrubs of Ethiopia and Eritrea, Fauna and Flora International, Cambridge, UK, 2005.

Woldemariam, M.: Suffering Under God's Environment: a Vertical Study of the Predicament of Peasants in North-Central Ethiopia, African Mountains Association and Geographica Bernensia, Bern, Switzerland, 1992.

Yu, Y. and Jia, Z. Q.: Changes in soil organic carbon and nitrogen capacities of Salix cheilophila Schneid along a revegetation chronosequence in semi-arid degraded sandy land of the Gonghe Basin, Tibet Plateau, Solid Earth, 5, 1045-1054, doi:10.5194/se5-1045-2014, 2014. 